\title{
Intercultural Competence of Students in International Baccalaureate World Schools in Turkey and Abroad
}

\author{
Şerife DEMIRCIOĞLU ${ }^{1} \&$ Cemal ÇAKIR ${ }^{1}$ \\ ${ }^{1}$ Department of English Language Teaching, Gazi University, Ankara, Turkey \\ Correspondence: Şerife DEMIRCIOĞLU, Gazi University, Faculty of Gazi Education, Department of English \\ Language Teaching, 06500, Ankara, Turkey. E-mail:serifeaydogan@yahoo.com
}

Received: December 12, 2015

Accepted: March 11, $2016 \quad$ Online Published: August 25, 2016

doi:10.5539/ies.v9n9p1

URL: http://dx.doi.org/10.5539/ies.v9n9p1

\begin{abstract}
This study investigates intercultural competence of International Baccalaureate Diploma Programme (IBDP) students and non-IBDP students and whether it is affected by some variants such as grade, gender, nationality, being a native speaker of English, living in an English speaking country and travelling abroad. The data is gathered from the Intercultural Sensitivity Scale (ISS) and the demographic part. The results reveal that there isn't a significant difference in ISS scores of IBDP students, but there is a significant difference in ISS scores between IBDP and non-IBDP students. The ISS scores differed in gender, grade and living in an English speaking country.
\end{abstract}

Keywords: intercultural communicative competence, intercultural competence, international baccalaureate diploma programme, intercultural communication

\section{Introduction}

With globalization and international exchanges, high school students' multicultural and multi-linguistic experience has increased and this has made intercultural competence (IC) a prerequisite. Students should have "the ability to interact effectively and appropriately in intercultural situations, based on specific attitudes, intercultural knowledge, skills and reflection" (Deardorff, 2006, p. 5).

To overcome failure in communication, students need to possess a number of intercultural competencies and characteristics to be able to cope with intercultural experiences (Sen-Gupta, 2002; Sercu, 2002; Sercu et al., 2005; Byram \& Feng, 2005; Byram, 2008; Atay et al., 2009; Penbek et al., 2009; Zheng, 2014). Thus, IC requires students to "acquire the knowledge, skills, attitudes, and critical cultural awareness necessary to communicate interculturally" (Byram, 1997, p. 10).

In order to clarify the concept of IC, models of IC have been developed. Although there cannot be a 'one size fits all model,' most models include similar dimensions and vary in emphasis and detail of components. All include awareness (of both self and of others), an open-minded attitude, intercultural knowledge, and skills that lead to effective communication and behaviour as an outcome (Bloom, 1956; Byram, 1997; Deardorff, 2006; Gudykunst, 1993; Gudykunst \& Kim, 1984). To exemplify, Bennett (1993, pp. 21-71) developed a dynamic model to explain how individuals respond to cultural differences and how their responses evolve over time. Byram (2000, p. 7) explains that with some degree of intercultural competence a person is able to see the relationships between different cultures, both internal and external, and is able to mediate each in terms of the other, either for themselves or for others. Deardorff's pyramid-shaped model (2006) gives a clear picture for success in achieving intercultural competence. At the base of the pyramid sits a group of attitudes that includes respect, openness and curiosity. An open and respectful attitude toward other values and ideas combined with willingness and openness to learn about and explore another culture is absolutely essential for intercultural learning. On the next level, knowledge and comprehension that interacts with skills build on the foundation. In order to reach intercultural competence, a person must be self-aware and able to self-evaluate and then move to awareness and evaluation outside of themselves in relation to other cultures. At the very top of the pyramid is behaviour in relation to the sought after internal outcomes.

In Chen and Starosta's (1996) model, which is used in the research study, competence does not simply consist of one aspect. Instead, competence springs from an ability to be culturally aware, sensitive, and skilful. Each piece 
shows a different level of involvement-cognitive, affective, and behavioural-required to achieve competence.

The cognitive aspect of IC is represented by the concept of intercultural awareness that refers to the understanding of cultural conventions that affects how we think and behave. It provides an opportunity for the individual to develop an awareness of cultural dynamics and to discern multiple identities in order to maintain a state of multicultural coexistence. This is the ability of intercultural awareness, which comprises two aspects of understanding: self-awareness and cultural awareness (Brislin, Landis, \& Brandth, 1983; Pruegger \& Rogers, 1993).

The affective aspect of IC is represented by the concept of intercultural sensitivity that refers to the subjects' "active desire to motivate themselves to understand, appreciate, and accept differences among cultures" (Chen \&Starosta, 1998, p. 231). Intercultural sensitivity is the attitudinal starting point for intercultural competence. Bhawuk and Brislin (1992) state that

to be effective in other cultures, people must be interested in other cultures, be sensitive enough to notice cultural differences and also be willing to modify their behavior as an indication of respect for people of other cultures. A reasonable term that summarizes these qualities of people is intercultural sensitivity ( $\mathrm{p}$. 416).

As the above statement implies, IC demands, affectively, positive emotion that enables individuals to be sensitive enough to acknowledge and respect cultural differences.

The behavioural aspect of IC is represented by the concept of intercultural adroitness that refers to "the ability to get the job done and attain communication goals in intercultural interactions" (Chen \& Starosta, 1996, p. 367). It stresses how to act effectively in intercultural interactions. It consists of those verbal and nonverbal behaviours that enable us to be effective in interactions. Such behaviours include message skills, appropriate self-disclosure, behavioural flexibility, interaction management, and social skills.

Based on this conceptual model, in order to assess different dimensions of IC, Chen and Starosta (2000) further explicated the nature and components of intercultural sensitivity and developed an instrument, the Intercultural Sensitivity Scale (ISS), to measure the concept. The ISS proved to be a valid tool (Chen \& Starosta, 2000) and recognized as a reliable tool by researchers (Graf \& Harland, 2005; Nieto \& Zoller-Booth, 2010; Schuerholz-Lehr, 2007) for measuring intercultural sensitivity. For a clearer understanding and argument for choosing the ISS, the details about ISS are explained within the data collection instrument part.

A number of studies have pinpointed that students' degree of IC has been affected by different factors such as age, gender, overseas experiences or studying abroad. In Banos' (2006) study, it seems to be that neither the age nor the course shows significant differences about intercultural sensitivity of the students. By the way, sex seems to be an important variable because girls have significant greater intercultural sensitivity than boys. Yet, other studies indicate no relationship between gender and their level of IC (Matveev, 2002; Patricia, 2005; Mirzaei \& Forouzandeh, 2013). In Penbek, Yurdakul, and Cerit's study (2009), it is found that students' respect for different cultures improve with the level of engagement in international interactions. Some related studies (Jung, 2002; Jular, 2007; Williams, 2005; Hismanoglu, 2011) indicate that studying abroad or overseas experience had a positive effect on IC. The findings of these studies also highlight the need for further research to explore the students' level of IC by different variants with more details in order to explore how these factors affect IC.

Given that IC plays a key role in second language learning and teaching, second language teaching curricula and syllabi have been enriched on the basis of new insights for IC. As a distinct new model in education, the International Baccalaureate Organisation (IBO) was founded in 1968 in Switzerland, putting an emphasis on IC and international-mindedness. Given its expansion in recent years, the IBO may be the closest thing to an international system of K-12 education in existence (Drake, 2004) and the intercultural aspect of the IBDP is central to its mission and figures prominently in its promotion (Conner, 2008).

IC plays an important role in students' lives, especially in the IBDP students' because the IBDP diploma is internationally recognized. Thus, when an IBDP student graduates from the programme, there is a high possibility for him/her to apply to a university in a different country. For this reason, the programme aims to develop students' international-mindedness, and the English curriculum in the programme is designed to promote IC.

Because the economies and societies of the $21^{\text {st }}$ century are built upon increasing complexity and diversity, today's high school students will enter a world that demands increased cultural sophistication and the ability to communicate and collaborate across cultures (Suarez-Orozco, 2007) and there is a need for further research to study IC. Thus, this research is aimed to explore whether there is a significant difference in intercultural 
sensitivity of IBDP students from Turkey, the UK, Spain, and Mexico and non-IBDP students from Turkey and see to what extent their intercultural sensitivity is affected from different variants such as grade, gender, nationality, being a native speaker of English, living in an English speaking country and travelling abroad.

To this end, since IBDP is a recent development as an alternative educational model, it is worth investigating whether or not IBDP has been able to help students reach the learning outcomes. As IBDP curriculum is international, it is assumed that IBDP students, regardless of where they live in or their own culture, have IC to some extent when they graduate from the programme. In the light of the purposes of the research, the following research questions are explored:

1) Is there a significant difference in intercultural sensitivity level of IBDP students from Turkey, the UK, Spain, and Mexico?

2) To what extent do the factors related to IBDP students' background and cultural experiences affect their intercultural sensitivity?

3) Is there a significant difference in intercultural sensitivity level of IBDP students and non-IBDP students from Turkey?

4) To what extent do the factors related to non-IBDP students' background and cultural experiences affect their intercultural sensitivity?

\section{Methodology}

\subsection{Research Design}

The study followed a descriptive research design to describe what is in existence in respect to conditions or variables that are found in a given situation and broaden the research perspective providing a general picture. The research design is cross-sectional, comparing different population groups at a single point in time. The research survey covers the ISS developed by Chen and Starosta (2000) and 8 demographic questions about the students' background. An online survey is designed to collect data from IBDP students from different countries. The survey research is acquired based on the primary goal of obtaining information from a larger number of IBDP students. Lastly, this is a nonlinear study, meaning that participants complete the survey only once.

\subsection{Data Collection Procedure}

Before the pilot study, an e-mail was sent to Chen and Starosta to obtain consent to use the ISS. After getting their consent, the pilot study was conducted. The first draft of the survey was pilot-tested face to face with a small student group of twelve subjects. The input received was incorporated into the final survey that was sent out. Following the pilot study, the online version of the survey was prepared. When the students clicked on the student's link, they answered the questions and submitted their answers.

Firstly, the electronic invitation and the survey's link were sent to IBO to inform them about the study and to get the IBDP coordinators' e-mail addresses. IBO wrote that they could not share this information in order to ensure that coordinators are not submerged with e-mails. Thus, the invitation and survey's link were sent to the IBDP coordinators of IB World Schools through the IB website one by one for them to forward electronically to IBDP students in the programme. To be able to contact more IBDP schools, the survey was put on the IBDP Coordinators' Facebook pages, the IBDP Coordinators' LinkedIn sites, and the IBDP Coordinators' Twitter page.

Further follow-up was made with individual participants to clarify any questions that were not clear or that had the potential for misinterpretation. Students were informed in the electronic invitation that participation in this study was on a voluntary basis. The procedures were detailed to preserve the anonymity and protect the confidentiality of the participants. Participant identity remained anonymous throughout the research process, as scores were linked only to the identification code assigned to the students. As for non-IBDP students, the paper-based survey was implemented in a private and an Anatolian high school in Ankara, Turkey.

\subsection{Sample}

For the purposes of this research, 1273 IB World Schools implementing IBDP were invited to participate in this study and 25 IB World Schools accepted the invitation. Since 25 schools in different countries accepted the request, it was a random grouping of locations and schools. That's why IBDP schools in Mexico, Spain, the UK, and Turkey are compared. One private and a state high school in Ankara, Turkey, also participated in the research. Altogether, 188 subjects (113 IBDP students and 75 non-IBDP students) comprised the study group. All the students had the English ability to complete the survey.

The profile of 113 IBDP students can be summarized as follows: 
- $\quad 28.3 \%$ live Turkey; $26.5 \%$ in Spain; $24.7 \%$ in the UK; and $20.3 \%$ in Mexico.

- $\quad 56.6 \%$ are in the $11^{\text {th }}$ grade and $43.3 \%$ in the $12^{\text {th }}$ grade.

- $\quad 52.2 \%$ are female and $47.7 \%$ male.

- $\quad 27.4 \%$ are native speakers of English (NSE) and 72.5\% non-native speakers of English (NNSE).

- $\quad 41.5 \%$ have lived in an English-speaking country and 58.4\% have not.

- $\quad 92.9 \%$ have travelled abroad; $7 \%$ have not.

75 non-IBDP students have participated in the study, all of whom live in Ankara, Turkey. 53.3\% are students of a private high school and $46.6 \%$ are in a state Anatolian high school. The profile of the non-IBDP students in a private high school can be summarized as follows:

- $55 \%$ are in the $11^{\text {th }}$ grade and $45 \%$ in the $12^{\text {th }}$ grade.

- $\quad 52.5 \%$ are female and $47.5 \%$ male.

- $\quad 2.5 \%$ are NSE and $97.5 \%$ NNSE.

- $\quad 17.5$ have lived in an English-speaking country and 82.5\% have not.

- $\quad 57.5 \%$ have travelled abroad; $42.5 \%$ have not.

The profile of the non-IBDP students in a state school can be summarized as follows:

- $\quad 54.2 \%$ are in the $11^{\text {th }}$ grade and $45.7 \%$ in the $12^{\text {th }}$.

- $\quad 57.1 \%$ are female and $142.8 \%$ male.

- $\quad$ None of the students are NSE and $100 \%$ are NNSE.

- $\quad 11.4 \%$ have lived in an English-speaking country and $88.5 \%$ have not.

- $\quad 34.2 \%$ have travelled abroad; $65.7 \%$ have not.

\subsection{Data Collection Instrument}

The research survey has 2 different parts. The first part covers 8 demographic questions about the students' background (grade, gender, nationality, being a native speaker of English, living in an English speaking country and travelling abroad) to create their individual profiles and measure the variance and relationship between the international experience variables and the ISS scores. The reason of choosing these variables is that as Tamam stated (2010), some variables may cause a greater variance in intercultural sensitivity scores. Williams argued that (2005, p. 369) that "exposure to various cultures is the best predictor of intercultural communication skills", travelling abroad and living in an English speaking country may also have an influence on intercultural sensitivity.

The second part is the ISS developed by Chen and Starosta (2000). In order to measure the dimensions of IC, Chen and Starosta (2000) first developed an instrument to explore the concept of intercultural sensitivity. According to Chen and Starosta (1997), intercultural sensitivity is comprised of four elements: self-concept, open-mindedness, non-judgmental attitudes and social relaxation.

Self-concept refers to the way in which a person sees him or herself. An individual's self-concept not only serves as his or her key to communication, but it mediates how the person relates to the world. One of the most important elements of self-concept is self-esteem. Persons with high self-esteem are more likely to think well of others, are more accepted by others, feel more comfortable when working with superiors (Adler and Towne, 1993).

Open-mindedness refers to individuals' willingness to express themselves openly when it is appropriate and to accept others' explanations. This trait is parallel to one of multicultural person, who thinks that variety is richness.

Being non-judgmental means holding no prejudices that will prevent one from listening sincerely to others during intercultural communication. Nonjudgmental and open-mindedness attitudes improve a feeling of enjoyment of cultural differences in intercultural interactions.

Finally, social relaxation refers to the ability to reveal little anxious emotion in intercultural communication. In the first encounter, it is assumed that one can feel anxious and under pressure and can have some crises. To be competent in intercultural communication, an individual must overcome feeling of anxiety when communicating with those from different cultures (Barna, 1994, p. 340). 
In the light of these concepts, ISS covers 24 statements about intercultural sensitivity of students on a 5-point scale (from $1=$ strongly disagree to $5=$ strongly agree) with nine items reverse-scored. The scale is intended to measure individuals' feelings about interacting with people who have different cultural backgrounds. It includes five sub-scales as follows:

1) Interaction Engagement of respondents is measured with 7 questions like "I am open- minded to people from different cultures."

2) Respect for Cultural Differences of respondents is measured with 6 questions like "I think my culture is better than the other culture."

3) Interaction Confidence of respondents is measured with 5 questions like "I find it very hard to talk in front of people from different cultures."

4) Interaction Enjoyment of respondents is measured with 3 questions like "I often get discouraged when I am with people from different cultures."

5) Interaction Attentiveness of respondents is measured with 3 questions like "I am very observant when interacting with people from different cultures."

The reason for choosing this scale is that Chen and Starosta's ISS is "the only scientific survey so far assessing the emotional dimension of intercultural competence" (Fritz et al., 2005, p. 54). Also, its construction followed the validity and reliability guidelines (Chen \& Starosta, 2000; Wolfgang, Mollenberg, \& Chen, 2002 cited in Graf \& Harland, 2005). The empirical construction and validation of the instrument of intercultural sensitivity were conducted in three stages and the results were found satisfactory. The scale demonstrated high internal consistency with a .86 reliability coefficient. It also takes into consideration all of the dimensions of IC and has specific intentions to measure intercultural sensitivity of different groups of people.

As for the reliability of the ISS, it has been used by multiple researchers in recent studies to assess intercultural sensitivity and found to be valid and reliable. Fritz and Mollenburg (1999) tested the validity on a group of German students, and the results were quite good. Similarly, Peng et al. (2005) measured the intercultural sensitivity levels of Thai and Chinese nationals, and again, the results were found to be quite reliable.

In the present study, the alpha coefficient for twenty-four items in the ISS scores of IBDP students is .818, suggesting that the items have relatively high internal consistency. Similarly, the alpha coefficient for the items in the ISS scores of non-IBDP students is .816 . The scale has a strong reliability as a whole, so sub-scales are not taken as a separate scale. Since there are three items in Interaction Enjoyment and Interaction Attentiveness sub-scales, the reliability of these two sub-scales is not substantially high. This finding is parallel with the study carried out by Fritz, Mollenberg, and Chen (2001). The lower reliability coefficients indicate that new items may be added to capture the concepts measured. Additionally, all the items appeared to be worthy of retention. The overall alpha is .818 , so all the values are around that same value. Removal of any item would result in a lower Cronbach's alpha. Therefore, none of the items can be removed from the scale.

\subsection{Data Analysis}

In the present study, the research survey consists of two parts: demographic questions and ISS. The SPSS statistics software package is used for the statistical analysis of the data. The data is analyzed using a $95 \%$ confidence level $(\alpha=.05)$. Means for the sample sizes and the standard deviations are also calculated and these are used as a basis for the comparative analysis. Also, one-way analysis of variance (one-way ANOVA) is used to compare means of four samples at one time to determine whether there are any significant differences between the means of four independent groups as the single scaled outcome (dependent) variable and four groups as the explanatory (independent) variable (Weinberg \& Abramowitz, 2002). When performing an ANOVA, several assumptions about the collected data must be considered:

- The ISS scores for each group are checked to determine that they are normally distributed. The non-parametric Kolmogorov-Smirnov (K-S) test is used to test the normality assumption. The output shows that for a sample size of 188 consisting of all IBDP and non-IBDP students, the mean is 94.9 with a minimum GPA of 69 and a maximum of 119 . Since the p-value is .200 and greater than .05 , the normality assumption is not rejected and it can be concluded that the distribution is normal.

- The ISS scores for each group are checked to determine that the variances are equal. The Levene test for Equality of Variances is used to test this assumption.

- It is necessary that all groups must be distinct and independent of one another.

Additionally, an independent-samples t-test is conducted to compare the means of the ISS in terms of grade, 
gender, nationality, being a native speaker of English, living in an English speaking country and travelling abroad.

\section{Results}

Research question 1: Is there a significant difference in ISS scores of IBDP students from Turkey, the UK, Spain, and Mexico?

ANOVA is used to compare the means of ISS of IBDP students from the UK, Turkey, Spain, and Mexico and to determine whether any of those means is significantly different from each other.

Table 1. Descriptives of IBDP students' ISS scores

\begin{tabular}{lccc}
\hline Students in & $\mathrm{n}$ & $\mathrm{M}$ & $\mathrm{SD}$ \\
\hline The UK & 28 & 96.96 & 1.17 \\
Turkey & 32 & 98.06 & 1.44 \\
Spain & 30 & 93.90 & 1.46 \\
Mexico & 23 & 97.34 & 2.04 \\
Total Group & 113 & 96.53 & .76 \\
\hline
\end{tabular}

The maximum possible score of the ISS is 100 and Table 1 shows that the intercultural sensitivity of IBDP students is relatively high. Its distribution has a mean of 96.53 . While the minimum score is 73 , the maximum score is 119. The significance level for the one-way ANOVA test is $\alpha=0.05$. The test for homogeneity of variance is significant $[$ Levene $F(.912)=.438, p>.05]$ indicating that the variance within each of the populations is equal.

Table 2. Analysis of variance for IBDP students' ISS scores

\begin{tabular}{lccccc}
\hline Source & $S S$ & $d f$ & $M S$ & $F$ & $p$ \\
\hline Between Groups & 303.31 & 3 & 101.10 & 1.54 & .206 \\
Within Groups & 7114.75 & 109 & 65.27 & & \\
Total & 7418.07 & 112 & & & \\
\hline
\end{tabular}

The one-way ANOVA of ISS $(F(3.109)=1.54, p=.206)$ indicates that there is not a statistically significant difference in the means of the ISS of four groups in Table 2. Since there is not a significant difference in the means of ISS of four groups, there is no need to determine which of these four groups differ from each other. This discloses that ISS scores of IBDP students do not change although the students live in different countries and have different cultures.

Research question 2: To what extent do the factors (grade, gender, being a native speaker of English, living in an English speaking country and travelling abroad) related to IBDP students' background and cultural experiences affect their intercultural sensitivity?

An independent-samples t-test is conducted to compare the means of ISS of IBDP students in terms of being in $11^{\text {th }}$ and $12^{\text {th }}$ grade. These results suggest that there is not a significant difference in the means for being in $11^{\text {th }}$ grade and $12^{\text {th }}$ grade.

Table 3. Independent t-test results of IBDP Students based on gender

\begin{tabular}{lcccccc}
\hline Grade & $\mathrm{N}$ & $\mathrm{M}$ & $\mathrm{S}$ & $\mathrm{df}$ & $\mathrm{t}$ & $\mathrm{P}$ \\
\hline Male & 54 & 94.7 & 7.3 & 111 & 2.26 & .025 \\
Female & 59 & 98.1 & 8.5 & & & \\
\hline
\end{tabular}


The results in Table 3 indicate that there is a statistically significant difference $(p=.025)$ in the means of male and female students. Since the mean of female students is greater than the mean of male students, one can conclude that female students have more intercultural sensitivity than male students. This finding is in parallel with the finding of Banos' study (2006), that is, gender seems to be an important variable because girls have significantly greater intercultural sensitivity than boys.

The results show that there is not a significant difference in means of ISS in terms of being a NSE $(M=97.2$, $\mathrm{SD}=74)$ or NNSE $(\mathrm{M}=96.2, \mathrm{SD}=8.4), \mathrm{t}(111)=.549, \mathrm{p}=.584$.

As for the factor 'living in an English speaking country', it is seen that the p-value is higher than 0.05 . The mean obtained for the students living in an English-speaking country is 97 and the SD is 7.3 while the mean is 96.1 and the SD is 8.7 for the students who have not lived in an English speaking country. Accordingly, there is no statistically significant difference between the two groups.

The results show that there is not a significant difference in the means of ISS in terms of having travelled abroad $(\mathrm{M}=97, \mathrm{SD}=7.3)$ or $\operatorname{not}(\mathrm{M}=96.1, \mathrm{SD}=8.7) \mathrm{t}(111)=.552, \mathrm{p}=.582$.

Research question 3: Is there a significant difference between the intercultural sensitivity scores of IBDP students and non-IBDP students from Turkey?

ANOVA is used to compare the means of ISS scores of IBDP students and non-IBDP students from a private and a state school in Turkey and to determine whether any of those means is significantly different from each other.

Table 4. Descriptives of ISS Scores of IBDP and non-IBDP students

\begin{tabular}{lccc}
\hline Students in Different Schools & $\mathrm{n}$ & $\mathrm{M}$ & $\mathrm{SD}$ \\
\hline IBDP students & 32 & 98 & 8.19 \\
Non-IBDP sts in a private school & 40 & 92.9 & 8.64 \\
Non-IBDP sts in a state school & 35 & 91.9 & 9.51 \\
Total Group & 107 & 94.1 & 9.11 \\
\hline
\end{tabular}

Table 4 shows that the intercultural sensitivity scores of IBDP and non-IBDP students are high. Its distribution has a mean of 94.1 . While the minimum score is 69 , the maximum score is 114 . The test for homogeneity of variance is significant [Levene $F(.427)=.653, p>.05]$ indicating that the variance within each of the populations is equal.

Table 5. Analysis of variance for ISS

\begin{tabular}{lccccc}
\hline Source & $S S$ & $d f$ & $M S$ & $F$ & $p$ \\
\hline Between Groups & 722.379 & 2 & 361.190 & 4.649 & .012 \\
Within Groups & 8080.518 & 104 & 77.697 & & \\
Total & 8802.897 & 106 & & & \\
\hline
\end{tabular}

Table 5 indicates that the ISS scores for IBDP students in Turkey is significantly higher $(M=98, S D=8.19)$ than non-IBDP students in a private school $(M=92.9, S D=8.64)$ and a state school $(M=91.9, S D=9.5), F(2,104)=$ $4.64, p=.012$. Since there is a significant difference in the means of ISS for the three groups, to specify what kind of difference and where the difference is, a follow up test called a post-hoc test is used. As the assumption of homogeneity of variance has been met (Equal Variances Assumed), the most commonly used test, the Tukey (HSD) test, is used. 
Table 6. Turkey post hoc results of IBDP and non-IBDP students' ISS scores

\begin{tabular}{|c|c|c|c|c|}
\hline (I) Students & (J) Students & $\begin{array}{c}\text { Mean } \\
\text { Difference (I-J) }\end{array}$ & Std. Error & Sig. \\
\hline \multirow{2}{*}{ IBDP sts } & IBDP sts in a private school & $5.11250^{*}$ & 2.09057 & .042 \\
\hline & Non-IBDP sts in a state school & $6.14821^{*}$ & 2.15591 & .014 \\
\hline \multirow{2}{*}{$\begin{array}{l}\text { Non-IBDP sts in a } \\
\text { private school }\end{array}$} & IBDP students & $-5.11250^{*}$ & 2.09057 & .042 \\
\hline & Non-IBDP sts in a state school & 1.03571 & 2.04018 & .868 \\
\hline \multirow{2}{*}{$\begin{array}{l}\text { Non-IBDP sts in a } \\
\text { state school }\end{array}$} & IBDP students & $-6.14821^{*}$ & 2.15591 & .014 \\
\hline & Non-IBDP sts in a private school & -1.03571 & 2.04018 & .868 \\
\hline
\end{tabular}

* The mean difference is significant at the 0.05 level.

The results in Table 6 indicate that there is a significant difference in ISS scores between non-IBDP students in a private school and IBDP students $(p=0.042)$, as well as between non-IBDP in a state school and IBDP students $(p=0.014)$. However, there were no differences between non-IBDP students in a private school and non-IBDP students in a state school $(p=0.868)$.

Research question 4: To what extent do the factors (grade, gender, being a native speaker of English, living in an English speaking country and travelling abroad) related to non-IBDP students' background and cultural experiences affect their intercultural sensitivity?

An independent-samples t-test is used to find out if the means of ISS scores of non- IBDP students is significantly different from one another or if they are relatively the same in terms of being in $11^{\text {th }}$ or $12^{\text {th }}$ grade. These results in Table 7 suggest that there is a significant difference in the means based on whether a student is in $11^{\text {th }}$ grade or $12^{\text {th }}$ grade, in favour of $11^{\text {th }}$ grade.

Table 7. Independent t-test results for non IBDP students' ISS scores based on grade

\begin{tabular}{lcccccc}
\hline Grade & $\mathrm{N}$ & $\mathrm{M}$ & $\mathrm{S}$ & $\mathrm{df}$ & $\mathrm{t}$ & $\mathrm{p}$ \\
\hline 11 & 41 & 94.6 & 8.1 & 73 & 2.3 & .021 \\
12 & 34 & 89.8 & 9.4 & & & \\
\hline
\end{tabular}

Table 8 shows that there is not a statistically significant difference $(\mathrm{p}=.15)$ in the means of male $(\mathrm{M}=90.8$, $\mathrm{SD}=8.7)$ and female students $(\mathrm{M}=93.8, \mathrm{SD}=9) ; \mathrm{t}(1.4), \mathrm{p}=.15$.

Table 8. Independent t-test results of non-IBDP Students' ISS scores based on gender

\begin{tabular}{lcccccc}
\hline Grade & $\mathrm{N}$ & $\mathrm{M}$ & $\mathrm{S}$ & $\mathrm{df}$ & $\mathrm{T}$ & $\mathrm{p}$ \\
\hline Male & 34 & 90.8 & 8.7 & 73 & 1.4 & .15 \\
Female & 41 & 93.8 & 9 & & & \\
\hline
\end{tabular}

Since only one student is a NSE among the participants, the difference of means of non-IBDP students in terms of being NSE or NNSE is not analyzed.

It is seen in Table 9 that the mean obtained for the students living in an English-speaking country is 98.5 and the standard deviation is 6 while the mean for the students who have not lived in an English-speaking country is 91.4 and the standard deviation is 9 . With a $95 \%$ degree of confidence, the table shows that there is a statistically significant difference between the two groups: $\mathrm{t}=2.5$ and $\mathrm{p}=.014$. 
Table 9. Independent t-test results for non-IBDP Students in terms of living in an English- speaking country

\begin{tabular}{lcccccc}
\hline Living in an English- speaking country & $\mathrm{N}$ & $\mathrm{M}$ & $\mathrm{S}$ & $\mathrm{df}$ & $\mathrm{t}$ & $\mathrm{p}$ \\
\hline Yes & 11 & 98.5 & 6 & 73 & 2.5 & .014 \\
No & 64 & 91.4 & 9 & & & \\
\hline
\end{tabular}

As for the factor 'travelling abroad', the mean of non-IBDP students who have travelled abroad is 94.6 and the standard deviation is 7.9. The mean of non-IBDP students who have not travelled abroad is 90.5 and the standard deviation is 9.5 . The p-value is .051 which suggests that there is not a significant difference in the means of two groups.

\section{Discussion}

The study yields some significant findings regarding IBDP and non-IBDP students' IC levels. The first thing that the results of the study reveal is that the intercultural sensitivity of IBDP students is relatively high and its distribution has a mean of 96.53. This reinforces earlier findings from a study assessing students' intercultural sensitivity (Spinthourakis et al., 2009). The result also shows that there is a significant difference in the mean of ISS scores between IBDP students and non-IBDP students in a private and a state high school in Turkey. The result discloses that ISS scores of IBDP students from four different countries do not change according to the country students live in or their culture. Using Chen and Starosta's (1997) conceptualization of intercultural sensitivity, it can be concluded that the majority of the respondents have a high "positive emotion towards understanding and appreciating cultural differences" and as a result, they also "promote appropriate and effective behaviour in intercultural communication". A possible explanation of these results is that an IB education creates learning communities in which students can increase their understanding of language and culture, which can help them to become more globally engaged. To increase intercultural understanding, IB programmes foster learning how to appreciate critically many beliefs, values, experiences and ways of knowing. It has a curriculum that is used globally and places the development of intercultural understanding and competence at its center (Conner, 2008).

Additionally, for the IB, learning to communicate in a variety of ways in more than one language is fundamental to the development of intercultural understanding. IB programmes, therefore, support complex, dynamic learning through wide-ranging forms of expression (IBO, 2015). All IB programmes require students to learn another language. IBDP students in Turkey, Mexico and Spain take all the courses in English and all IBDP students learn another language offered by their school. When people with different linguistic and cultural backgrounds interact socially, they bring along with them their knowledge about their own cultural environments and that of other people (Byram, 1997; Kramsch, 2013). This may be the fact that learning to communicate in a variety of ways in more than one language is fundamental to the development of intercultural understanding.

However, the result of the study is not parallel with Keller's study (2010), which demonstrated that there was no statistically significant change in the global-mindedness of general education students who attend an IB World School. This finding highlights the need for further research to explore IBDP students' IC differences in different contexts by employing both quantitative and qualitative methods as well as a larger sample.

Secondly, to what extent the factors related to IBDP students' background and cultural experiences affect their intercultural sensitivity is examined. The result uncovers that there is not a significant difference in the means for being in $11^{\text {th }}$ grade or $12^{\text {th }}$ grade. This result is in line with the result of a similar study by Spinthourakis et al. (2009). This may be due to the fact that participants are the students in an international diploma programme and they are exposed to intercultural philosophy from the beginning of the programme. Generally, IB World Schools start to prepare IBDP students for the programme in the $9^{\text {th }}$ and $10^{\text {th }}$ grades. Additionally, some students have already started the IB programme in the primary or middle school thanks to the IB Primary Years or IB Middle Years Programmes.

Moreover, there is not a significant difference in the means of ISS scores in terms of being a NSE or NNSE, living in an English-speaking country, and having travelled abroad. This may result from the fact that students are able to have more experiences in today's society as travel is much easier and safer and there are programmes for students to study abroad, volunteer abroad, and go on adventures abroad. This enables students to have more opportunities to interact with new and different cultures, thereby giving them a higher level of intercultural sensitivity. Additionally, since international-mindedness is in the centre of IB philosophy, IBDP students have lots of opportunities to get intercultural training in different subjects, especially in English course. In contrast to the study's results, overseas experiences or studying abroad has been reported to be a significant factor to affect 
students' high level intercultural communication knowledge (Jung, 2002; Jular, 2007; Williams, 2005; Hismanoglu, 2011). This finding also highlights the need for further research about the relation between overseas experiences and IC.

The only statistically significant difference is seen in gender. The mean of female students is greater than that of male students. Gender also showed a statistically significant, positive relationship in McMurray's (2000) study. Hayden and Wilkinson (2010) sought to explore changes in attitudes relating to six of the main IB aims. In terms of "intercultural understanding", there was greater movement towards this aim for females than males. Also, the results are consistent with some published studies (Tannen, 1994; Clark \& Trafford, 1995; Sung \& Padilla, 1998; Kouritzin, 2000; Kim \& Goldstein, 2005; Kobayashi, 2007; Pan, 2007; Warriner, 2007). This may be due to the fact that in many cultures, women are raised to be more aware of and attuned to the feelings and nuances that go with them than men are (Goleman, 1998). This means that the female students in this study may have a higher level of empathy, making it easier for them to be culturally aware, thus eventually leading to a higher level of intercultural sensitivity. However, these results differ from findings of some published studies (Matveev, 2002; Patricia, 2005; Mirzaei \& Forouzandeh, 2013; Saricoban \& Oz, 2014). This finding also highlights the need for further research to explore gendered IC differences.

The third research question compares the ISS of IBDP students to those of non-IBDP students in a private high school and to those of non-IBDP students in a state high school from Turkey. The results display that the ISS scores of IBDP and non-IBDP students from Turkey are high. Since the ISS scores of IBDP students in Turkey was significantly higher than non-IBDP groups in two different schools, the Tukey test is implemented. The result shows that there is a significant difference in the mean of ISS scores between non-IBDP students in a private school and IBDP students and as well as between non-IBDP students in a state school and IBDP students. However, there is not a significant difference between non-IBDP students in a private school and non-IBDP students in a state school. There may be various reasons for IBDP students to have a higher level of intercultural sensitivity, for instance, studying an international curriculum, having opportunities for participating in intercultural events, and engaging in a range of types of exchange, not only direct contact but also indirectly through media channels. Henrichs concluded that the IB may be effective in promoting international understanding, as measured by a questionnaire designed to measure "world perspective values" (Henrichs, 2002). According to Hayden and Wong's study (1997), IBDP students are perceived to have an "international attitude". It is important, therefore, to investigate IBDP and non-IBDP students and do more research about IC.

The fourth research question focuses on the extent that factors related to non-IBDP students' background and cultural experiences affect their intercultural sensitivity. Although there is not a significant difference in IBDP students' ISS scores in terms of grade, there is a significant difference in the mean of non-IBDP students for being in $11^{\text {th }}$ grade and $12^{\text {th }}$ grade in favour of $11^{\text {th }}$ grade. In contrast to IBDP students' ISS scores, there is a statistically significant difference in the mean of non-IBDP students' ISS scores in terms of living in an English speaking country. Whereas gender is a significant factor in the IBDP students' ISS scores, there is not a statistically significant difference in the means of male and female students in non-IBDP group. In IBDP and non-IBDP students' ISS scores, it is seen that there is not a significant difference in terms of having travelled abroad.

\section{Conclusion}

The main goal of the current study was to investigate IC of IBDP students from Turkey, Spain, Mexico and the UK and non-IBDP students from Turkey whether students' IC levels are affected by some variants. The findings revealed that there is not a significant difference in ISS scores of IBDP students from different countries. Furthermore, the findings also showed that there was no significant difference between the subjects' IC levels and their grades, being a native speaker of English, living in an English speaking country and travelling abroad. It is important to note that the findings of the research study revealed that the students' gender had a significant difference in subject's IC level in favor of female subjects.

As the results indicate, there is a significant difference between Turkey's non-IBDP students' scores and Turkey's IBDP students' scores. There still seems to be a gap in terms of the general level of non-IBDP students' intercultural sensitivity. This could be as a result of the foreign language teaching policy and the English language teachers' approach to intercultural language teaching in Turkey.

Taken together, these findings indicate that being a student in an international programme, learning more than one language and getting IC training in each course, especially in English course, can have a positive effect on students' IC levels. Thus, curriculum developers and syllabus designers should integrate key concepts of intercultural education during the curriculum development process. 


\section{Recommendation}

The findings of the current study enhance the understanding of the IC of IBDP and non-IBDP students. Therefore, the concept 'IC' needs to be defined by language teachers and the administration in the schools. School administration can provide in-service training about intercultural language training. Pre-service teacher training programmes should involve an intercultural training course to inform prospective teachers about intercultural language teaching and help them to gain knowledge and skills to integrate IC in their course. Since behavioural skills in IC emphasize the significance of communication skills, the field of communication should contribute to the English language teaching. Also, an interdisciplinary approach should be taken into consideration.

\section{Limitations}

Like other studies in social sciences, this study is not without its limitations. Firstly, the sample consisted of 113 IBDP students and 75 non-IBDP students. A future study with a larger group may be needed to confirm the consistency of the study. Second, only IBDP students' IC levels in four countries and non-IBDP students in Turkey were examined. The IBDP students and non-IBDP students in other countries can be the sample of the study. The data were collected by a single administration design using a questionnaire. Further research may include interviews to further examine IC in such foreign language contexts.

\section{References}

Adler, R. B., \& Towne, N. (1993). Looking out/Looking in. New York: Harcourt Brace Jvanovich.

Atay, D., Kurt, G., Camlibel, Z., Ersin, P., \& Kaslioglu, O. (2009). The role of intercultural competence in foreign language teaching. Inonu University Journal of the Faculty of Education, 10, 123-135.

Banos, R. V. (2006). Intercultural sensitivity of teenagers: A study of educational necessities in Catalonia. Intercultural Communication Studies XV: 2.

Barna, L. M. (1994). Intercultural communication stumbling blocks. In L. A. Samovar, \& R. E. Porter (Eds.), Intercultural communication: A reader (pp. 337-346). Belmont, CA: Wadsworth.

Bennett, J. M. (1993). Toward Ethnorelativism: A developmental model of intercultural sensitivity. In R. M. Paige (Ed.), Education for the Intercultural Experience. Yarmouth: ME: Intercultural.

Bhawuk, D. P. S., \& Brislin, R. (1992). The measurement of intercultural sensitivity using the concepts of individualism and collectivism. Intercultural Journal of Intercultural Relations, 16, 413-436. http://dx.doi.org/10.1016/0147-1767(92)90031-O

Bloom, B. S. (1956). Taxonomy of educational objectives, the classification of educational goals-handbook I: Cognitive Domain. New York: McKay.

Brislin, R. W, Landis, D., \& Brandt, M. E. (1983). Conceptualizations of intercultural behaviour and training. In D. Landis, \& R. W. Brislin (Eds.) Handbook of Intercultural Training: Vol. 1 Issues in theory and design (pp. 1-35) Elmsford, NY: Pergamon.

Byram, M., \& Feng, A. (2005). Teaching and researching intercultural competence. In E. Hinkel (Ed.), Handbook of Research in Second Language Teaching and Learning (pp. 911-930). Mahwah, NJ: Lawrence Erlbaum.

Byram, M. (1997). Teaching and assessing intercultural communicative competence. London: Multilingual Matters.

Byram, M. (2000). Assessing intercultural competence in language teaching. Sprogforum, 18, 8-13.

Byram, M. (2008). From Foreign Language Education to Education for Intercultural Citizenship: Essays and Reflections. Clevedon: Multilingual Matters.

Chen, G. M., \& Starosta, W. J. (1996). Intercultural communication competence: a synthesis. In B. R. Burleson (Ed.), Communication Yearbook, 19, 353-384. http://dx.doi.org/10.1080/23808985.1996.11678935

Chen, G. M., \& Starosta, W. J. (1998). Foundation of intercultural communication. Boston, MA: Allyn, Bacon.

Chen, G. M., \& Starosta, W. J. (2000). The development and validation of the intercultural sensitivity scale. Educational Resources Information Centre (ERIC) ED 447525.

Clark, A., \& Trafford, J. (1995). Boys into modern languages: An investigation of the discrepancy in attitudes and performance between boys and girls in modern languages. Gender and Education, 7, 315-325. http://dx.doi.org/10.1080/09540259550039022 
Conner, J. O. (2008). From international schools to inner-city schools: The first principles of the International Baccalaureate Diploma Program. Teachers College Record, 110(2), 322-351.

Deardorff, D. K. (2006). Identification and assessment of intercultural competence as a student outcome of internationalization. Journal of Studies in International Education, 10(3), 241-266. http://dx.doi.org/10.1177/1028315306287002

Drake, B. (2004). International education and IB programmes: Worldwide expansion and potential cultural dissonance. Journal of Research in International Education, 3(2), 189-205. http://dx.doi.org/10.1177/1475240904044387

Fritz, W., Mollenberg, A., \& Werner, T. (1999). Die interkulturelle kompetenz von managern-ihre bedeutung für die managementpraxis und perspektiven für die forschung. Braunschweig: Technische Universität.

Frizt, W., Mollenberg, A., \& Chen, G. (2001). Measuring intercultural sensitivity in different cultural context. Presented at the Biannual Meeting of the International Association for the Intercultural Communication Studies.

Goleman, D. (1998). Working with emotional intelligence. New York: Bantam Books.

Graf, A., \& Harland, L. K. (2005) Expatriate Selection: Evaluating the Discriminant, Convergent, and Predictive Validity of Five Measures of Interpersonal and Intercultural Competence. Journal of Leadership and Organizational Studies, 11(2), 45-62. http://dx.doi.org/10.1177/107179190501100206

Gudykunst, W. B., \& Kim, Y. Y. (1984). Communicating with strangers: an approach to intercultural communication. New York: Random.

Gudykunst, W. B. (1993). Toward a theory of effective interpersonal and intergroup communication: An anxiety/ uncertainty management perspective. In R. L. Wiseman, \& J. Koester (Eds.), Intercultural communication competence (pp. 33-71). Newbury Park, CA: SAGE.

Hayden, M., \& Wilkinson, V. (2010). The International Baccalaureate Diploma and student attitudes: An exploratory study. Journal of Research in International Education, 9, 11.

Hayden, M., \& Wong, C. S. D. (1997). The International Baccalaureate: International education and cultural preservation. Educational Studies (03055698), 23(3), 349. http://dx.doi.org/10.1080/0305569970230302

Henrichs, J. (2002). The effect of the International Baccalaureate Diploma Programme on international understanding. IB Research Notes, 2(1), 3-9.

Hismanoglu, M. (2011). An investigation of ELT students' intercultural communicative competence in relation to linguistic proficiency, overseas experience and formal instruction. International Journal of Intercultural Relations, 35, 805-817. http://dx.doi.org/10.1016/j.ijintrel.2011.09.001

International Baccalaureate Organization. (2015). What is an IB education? UK: IBO.

Jular, E. M. (2007). The Development of Intercultural Awareness and Changes of Beliefs: The Effects of Studying Abroad on Learners of English as a Second Language. Retrieved from http://repositori.upf.edu/bitstream/handle/10230/1256/ElenaMerino.pdf

Jung, J. Y. (2002). Issues in acquisitional pragmatics. Working Papers in TESOL \& Applied Linguistics, 2, 1-34.

Keller, M. (2010). Global mindedness and internationalism: The effect of the International Baccalaureate Program on school wide attitudes of students. Union University, Tennessee.

Kim, R., \& Goldstein, S. B. (2005). Intercultural attitudes predict favorable study abroad expectations of U.S. college students. Journal of Studies in International Education, 9, 265-278. http://dx.doi.org/10.1177/1028315305277684

Kobayashi, Y. (2007). Japanese working women and English study abroad. World Englishes, 26, 62-71. http://dx.doi.org/10.1111/j.1467-971X.2007.00488.x

Kouritzin, S. (2000). Immigrant mothers redefine Access to ESL classes: Contradiction and ambivalence.

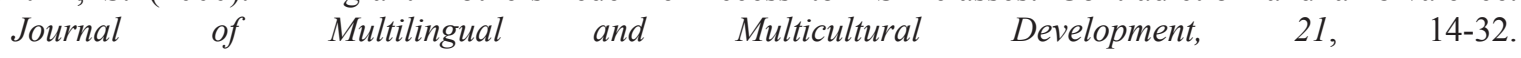
http://dx.doi.org/10.1080/01434630008666391

Kramsch, C. (2013). Culture in foreign language teaching. Iranian Journal of Language Teaching Research, 1 , 57-78.

Matveev, A. V. (2002). The Perception of Intercultural Communication Competence by American and Russian 
Managers with Experience on Multicultural Teams (Unpublished Ph. D. thesis). Athens, OH: Ohio University.

McMurray, A. (2007). Measuring intercultural sensitivity of international and domestic college students: the impact of international travel (M.A Thesis. University of Florida).

Mirzaei, A., \& Forouzandeh, F. (2013). Relationship between intercultural communicative competence and L2-learning motivation of Iranian EFL learners. Journal of Intercultural Communication Research, 42, 300-318. http://dx.doi.org/10.1080/17475759.2013.816867

Nieto, C., \& Zoller-Booth, M. (2010). Cultural competence: Its influence on the teaching and learning of international students'. Journal of Studies in International Education, 14(4), 406-425. http://dx.doi.org/10.1177/1028315309337929

Pan, S. (2007). Intercultural communication apprehension, ethnocentrism and their relationship with gender: A cross-cultural comparison between the U.S. and China. Paper presented at the annual meeting of the NCA 93rd Annual Convention, TBA, Chicago, IL. November 15, 2007.

Patricia, M. Y. (2005). Asian American Adolescents and the Stress of Acculturation: Differences in Gender and Generational Levels Unpublished Ph. D. thesis). Flagstaff, AZ: Northern Arizona University.

Penbek, D., Yurdakul, D., \& Cerit, A. G. (2009). Intercultural communication competence: A study about the intercultural sensitivity of university students based on their education and international experiences. Paper presented at the European and Mediterranean Conference on Information Systems, in Izmir, Turkey, July 13 to $14,2009$.

Peng, S. Y., Rangsipaht, S., \& Thaipakee, S. (2005). Measuring intercultural sensitivity: A comparative study of ethnic Chinese and Thai nationals. Journal of Intercultural Communication Research, 34(2), 119-137.

Pruegger, V. J., \& Rogers, T. B. (1993). Development of a scale to measure cross-cultural sensitivity in the Canadian context. Canadian Journal of Behaviour Science, 25, 615-621. http://dx.doi.org/10.1037/h0078846

Saricoban, A., \& Oz, H. (2014). Research into pre-service English teachers' intercultural communicative competence (ICC) in Turkish Context. The Antropologist, 18(2), 523-531.

Schuerholz-Lehr, S. (2007). Teaching for Global Literacy in Higher Education: How Prepared Are the Educators?'. Journal of Studies in International Education, 11(2), 180-204. http://dx.doi.org/10.1177/1028315307299419

Sen-Gupta, A. (2002). Changing the focus. A discussion of the dynamics of the intercultural experience. In G. Alred, M. Byram, \& M. Fleming (Eds.), Intercultural Experience and Education (pp. 155-178). Clevedon: Multilingual Matters.

Sercu, L. (2002). Implementing intercultural foreign language education: Belgian, Danish and British teachers' professional self-concepts and teaching practices compared. Evaluation \& Research in Education, 16, 150-165. http://dx.doi.org/10.1080/09500790208667015

Sercu, L., Bandura, E., Castro, P., Davcheva, L., Laskaridou, C., Lundgren, U., . . Ryan, P. (2005). Foreign Language Teachers and Intercultural Competence: An International Investigation. Clevedon: Multilingual Matters.

Spinthourakis, J. A., Karatzia-Stavlioti, E., \& Roussakis, Y. (2009). Pre-service teacher intercultural sensitivity assessment as a basis for addressing multiculturalism. Intercultural Education, 20(3), 267-276. http://dx.doi.org/10.1080/14675980903138624

Suarez-Orozco, M. M. (2007). Learning in the global era: International perspectives on globalization and education. Los Angeles, CA: University of California Press.

Sung, H., \& Padilla, A. (1998). Student motivation, parental attitudes, and involvement in the learning of Asian languages in elementary and secondary schools. The Modern Language Journal, 82, 205-216. http://dx.doi.org/10.1111/j.1540-4781.1998.tb01193.x

Tamam, E. (2010). Examining Chen and Starosta's Model of Intercultural Sensitivity in a Multiracial Collectivistic Country. Journal of Intercultural Communication Research, 39(3), 173-183.

Tannen, D. (1994). Gender and Discourse. Oxford: Oxford University Press.

Warriner, D. (2007). It's just the nature of the beast: Reimagining the literacies of schooling in adults ESL 
education. Linguistics and Education, 18, 279-295. http://dx.doi.org/10.1016/j.linged.2007.07.004

Weigberg, S., \& Abramowitz, S. K. (2002). Data analysis for the behavioural sciences using SPSS. USA: Cambridge University Press.

Williams, T. R. (2005). Exploring the impact of study abroad on students' intercultural communication skills: adaptability and sensitivity. Journal of Studies in International Education, 9, 356-371. http://dx.doi.org/10.1177/1028315305277681

Zheng, J. (2014). Assessing intercultural communicative competence in college English teaching. International Journal of English Language Teaching, 1,73-77. http://dx.doi.org/10.5430/ijelt.v1n2p73

\section{Copyrights}

Copyright for this article is retained by the author(s), with first publication rights granted to the journal.

This is an open-access article distributed under the terms and conditions of the Creative Commons Attribution license (http://creativecommons.org/licenses/by/4.0/). 